Vol 2. No 2. Agustus 2018

ISSN 2580-5029

\title{
Analisis Kadar Glukosa, Hemoglobin dan Kolesterol Mencit (Mus musculus) Setelah Diinduksi Aspartam
}

\author{
Esti Tyastirin ${ }^{*}$, Risa Purnamasari ${ }^{1}$, Irul Hidayati', Eva Agustina ${ }^{1}$, Moch. Irfan Hadi', Nova \\ Lusiana ${ }^{1}$, Mei Lina Fitri $\mathrm{K}^{1}$ \\ ${ }^{1}$ Universitas Islam Negeri Sunan Ampel Surabaya, Indonesia \\ *Esty50@gmail.com
}

\begin{abstract}
Aspartame has a lower calorie rating than other sweeteners. for example, cyclamate, lactose, saccharin, fructose and maltosa. Although it has low calorie, aspartame have 60 times sweeter than sugar (sucrose). Induction of aspartame can cause elevated levels of blood glucose and damage to the pancreatic $\beta$ cells of mice. The purpose of this study was to analyze the dosing of aspartame levels; $13 \mathrm{mg} / \mathrm{Kg}$ body weight, $39 \mathrm{mg} / \mathrm{Kg}$ and $78 \mathrm{mg} / \mathrm{Kg}$ and those effect to the levels of glucose, cholesterol and haemoglobin of female mice (Mus musculus). The methode of research laboratory experiments using a complete randomized design (RAL). This study was using 24 mice with 4 treatment groups. Mice were given aspartame during surgical treatment, mice were made to perform measurement of $\mathrm{Hb}$ levels, glucose levels and cholesterol levels of neonatal mice. Data analysis using the Kruskal Wallis because Gaussian data but not homogeneous. The results showed an increase in the levels of glucose and cholesterol levels, but statistically there is no difference in glucose levels $(p=0,087), \mathrm{Hb}(p=0,899)$ and cholesterol $(p=0,168)$ in mice (Mus musculus) who were given variations of the dose of aspartame.
\end{abstract}

Keywords: glucose, cholesterol, haemoglobin, aspartame

\begin{abstract}
ABSTRAK
Aspartam merupakan pemanis buatan yang memiliki nilai kalori lebih rendah dibandingkan pemanis lainnya misalnya, seperti siklamat, laktosa, sakarin, fruktosa dan maltosa. Meskipun memiliki kalori yang rendah, tetapi aspartam juga mempunyai rasa 60 kali lebih manis gula biasa (sukrosa). Induksi aspartam dapat menyebabkan peningkatan kadar glukosa darah dan kerusakan pada sel $\beta$ pankreas tikus. Tujuan penelitian untuk menganalisis pemberian dosis aspartam $13 \mathrm{mg} / \mathrm{Kg} \mathrm{BB}, 39 \mathrm{mg} / \mathrm{Kg}$ BB dan $78 \mathrm{mg} / \mathrm{Kg}$ BB terhadap kadar glukosa, haemoglobin dan kolesterol mencit (Mus musculus) betina. Jenis penelitian adalah eksperimen laboratorium dengan menggunakan rancangan acak lengkap (RAL). Sampel yang digunakan dalam penelitian ini yaitu hewan coba mencit sejumlah 24 ekor dengan 4 kelompok perlakuan. Mencit diberi aspartam selama masa perlakuan, pembedahan mencit dilakukan untuk melakukan pengukuran kadar glukosa, kadar $\mathrm{Hb}$ dan kadar kolesterol mencit tersebut. Analisis data menggunakan Kruskal Wallis karena data berdistribusi normal tetapi tidak homogen. Hasil penelitian menunjukkan terjadi peningkatan kadar glukosa dan kadar kolesterol, namun secara statistik tidak ada perbedaan kadar glukosa $(\mathrm{p}=0,087), \mathrm{Hb}(\mathrm{p}=0,899)$ dan kolesterol $(\mathrm{p}=0,168)$ pada mencit (Mus musculus) yang diberi variasi dosis aspartam.
\end{abstract}

Kata Kunci: glukosa, hemoglobin, kolesterol, aspartam 


\section{PENDAHULUAN}

Aspartam adalah pemanis sintesis non karbohidrat atau merupakan bentuk metal ester dari dipeptida dua asam amino yaitu asam amino asam aspartate dan asam amino essensial fenilalanin. Aspartam ini memiliki daya kemanisan kurang lebih dua ratus kali kemanisan sukrosa.

Aspartam itu sendiri merupakan pemanis buatan yang ditelah disetujui oleh FDA (Food Drug Administration) untuk dikonsumsi. Aspartam terdiri dari asam amino sehingga di dalam tubuh akan mengalami metabolisme menjadi 2 asam amino (asam aspartat dan Lfenilalanin). Hasil penguraian 2 asam amino dan metanol ini tidak akan menimbulkan efek yang berbahaya pada tubuh, oleh karena itu, aspartam merupakan salah satu bahan makanan yang aman bagi penderita diabetes melitus (Cahyadi, 2009).

Nilai kalori yang dimiliki aspartam lebih rendah dibandingkan pemanis lainnya misalnya, seperti siklamat, asesulfram, laktosa, sakarin, fruktosa dan maltrosa. Walaupun demikian aspartam mempunyai rasa 60 kali lebih manis gula biasa (sukrosa). Aspartam dipecah mengikuti dua jalur tergantung pada $\mathrm{pH}$, temperatur, dan kelembapan. pemecahan pertama melibatkan pemutusan ikatan ester dalam aspartam tersebut. Ikatan ester juga terhidrolisis membentuk dipeptida aspartil fenilalanin bedanya yaitu pada pemecahan yang kedua menghilangkan pembentukan methanol, pada akhirnya aspartil fenilalanin juga terhidrolisis untuk menjadi fenilalanin dan asam aspartam (Homler., et al, 1998).

Aspartam akan bereaksi dengan dua gugus SH yang berikatan pada bagian sisi dari protein atau asam amino membentuk ikatan disulfida sehingga protein menjadi tidak aktif yang berakibat pada gangguan fungsi protein tersebut. Mekanisme kerja aspartam dapat menyebabkan kerusakan pada sel-sel $\beta$ pankreas terutama akan menyerang senyawa-senyawa seluler yang mengandung gugus sulfidril, asamasam amino sistein dan protein yang berikatan dengan gugus SH (termasuk enzim yang mengandung gugus $\mathrm{SH}$ ). Induksi aspartam tersebut dapat menyebabkan peningkatan kadar glukosa darah dan kerusakan pada sel $\beta$ pankreas tikus. Mencit dianggap diabetes apabila memiliki kadar glukosa yang melebihi $140 \mathrm{mg} / \mathrm{dL}$ (Dalimartha, 2007).

Hemoglobin merupakan protein yang terdapat dalam sel darah atau eritrosit yang terdiri dari zat besi yang berguna sebagai pembawa oksigen. Hemoglobin berfungsi sebagai pengikat oksigen yang diedarkan ke seluruh tubuh. 
Glukosa merupakan karbohidrat yang berguna untuk sumber tenaga utama dalam tubuh, untuk sintesis semua karbohidrat lain dalam tubuh seperti glikogen,ribose dan deoxiribosa (Murray, et al. 2003).

Kolesterol adalah lipid ampifatik yang mendasari unsur dalam membran plasma dan lipoprotein plasma. Kolesterol merupakan prekusor dari hormon-hormon steroid dan asam lemak dan termasuk unsur terenting dalam membran sel (Ganong, 1995). Separuh dari kolesterol berasal dari proses sintesis (sekitar $700 \mathrm{mg} /$ hari) dan lainnya diperoleh dari makanan. Pada usus dan hati, masing- masing menghasilkan $10 \%$ dari sintesis total makhluk hidup. Menurut Murray (2006) menyatakan bahwa hampir semua jaringan yang memiliki sel berinti mampu membentuk kolesterol, yang berlangsung di retikulum endoplasma dan sitosol. Jadi kolesterol merupakan elemen esensial yang terdapat di dalam membran sel.

Penentuan kadar hemoglobin glukosa dan kolesterol dapat diukur dengan menggunakan beberapa alat. Pada penelitian ini alat yang digunakan adalah alat Easy touch GCHb. Alat tersebut memiliki kalibrasi sendiri dalam bentuk chip yang berfungsi untuk mencocokkan kode yang berada pada layar glukometer.
Alat tersebut digunakan pada masingmasing tabung pengukuran, kemudian hasil dari glukosa, hemoglobin dan kolesterol akan terbaca pada layar easy touch. Pengukuran kadar hemoglobin dan glukosa ini dimaksudkan sebagai pengetahuan mengenai kondisi fisik pada makhluk hidup (Campbell, 2004).

Tujuan Penelitian ini adalah untuk menganalisis pemberian dosis aspartam $13 \mathrm{mg} / \mathrm{Kg} \mathrm{BB}, 39 \mathrm{mg} / \mathrm{Kg} \mathrm{BB}$ dan 78 mg/Kg BB terhadap kadar glukosa, hemoglobin dan kolesterol mencit (Mus musculus) betina

\section{METODE}

Penelitian ini bersifat eksperimen laboratorium dengan menggunakan rancangan acak lengkap (RAL). Metode eksperimen yang dilakukan terhadap hewan coba yaitu mencit. Metode eksperimen ini untuk mengetahui akibat yang ditimbulkan dari suatu perlakuan yang diberikan dengan sengaja oleh peneliti yaitu aspartam dengan dosis yang berbeda-beda, dosis aspartam 100 $\mathrm{mg} / \mathrm{Kg} \mathrm{BB}, 300$ mg/Kg BB dan 600 mg/Kg BB pada manusia yang dikonversi ke mencit $(0,00026)$ dengan dosis $13 \mathrm{mg} / \mathrm{Kg}$ BB, $39 \mathrm{mg} / \mathrm{Kg}$ BB dan $78 \mathrm{mg} / \mathrm{Kg}$ BB. Hewan coba yang digunakan dalam penelitian ini adalah Mencit (Mus 
musculus) betina sejumlah 24 ekor dengan 4 kelompok perlakuan.

Penelitian dilakukan pada tanggal 22 Mei - 7 Juni 2018 di laboratorium terintegrasi UIN Sunan Ampel Surabaya selama 15 hari perlakuan hingga hari pembedahan. Mencit diberi aspartam selama masa perlakuan, pembedahan mencit dilakukan untuk melakukan pengukuran kadar glukosa, kadar $\mathrm{Hb}$ dan kadar kolesterol mencit tersebut. Analisis data menggunakan Kruskal Walis karena data berdistribusi normal tetapi tidak homogen

\section{HASIL DAN PEMBAHASAN}

Hasil penelitian pemberian dosis aspartam terhadap kadar glukosa mencit dapat dilihat pada tabel 1

Tabel 1. Kadar Glukosa

\begin{tabular}{|c|c|c|c|c|}
\hline \multirow[b]{2}{*}{ No } & \multirow[b]{2}{*}{$\begin{array}{c}\text { KEL. } \\
\text { KONTROL }\end{array}$} & \multicolumn{3}{|c|}{ KEL. PERLAKUAN } \\
\hline & & $\begin{array}{c}13 \\
\mathrm{mg} / \mathrm{Kg} \\
\mathrm{BB}\end{array}$ & $\begin{array}{c}39 \\
\mathrm{mg} / \mathrm{Kg} \\
\mathrm{BB}\end{array}$ & $\begin{array}{c}78 \\
\mathrm{mg} / \mathrm{Kg} \\
\mathrm{BB}\end{array}$ \\
\hline 1 & 151 & 204 & 179 & 403 \\
\hline 2 & 149 & 182 & 238 & 354 \\
\hline 3 & 132 & 286 & 152 & 155 \\
\hline 4 & 108 & 153 & 186 & 169 \\
\hline 5 & 183 & 208 & 249 & 124 \\
\hline 6 & 117 & 208 & 127 & 117 \\
\hline & 140,00 & 206,83 & 188,50 & 220,33 \\
\hline
\end{tabular}

Sumber: Data Primer, 2018

Berdasarkan tabel 1 rata-rata kadar glukosa mencit (Mus musculus) terdapat peningkatan setelah pemberian aspartam terutama pada dosis $78 \mathrm{mg} / \mathrm{Kg}$ BB yaitu 220,33 mg/dL. Hasil uji statistik dengan
Kruskal Wallis di dapatkan nilai 0,087 p $>0,05$ sehingga Ho diterima Ha ditolak tidak ada perbedaan kadar glukosa pada mencit yang diberi variasi dosis aspartam.

Pada penelitian ini pemberian aspartame tidak memberikan pengaruh terhadap peningkatan kadar glukosa darah, hal ini sesuai dengan penelitian Renwick (2006) menunjukkan bahwa reseptor rasa manis terdapat di usus halus pertama kali dideteksi oleh $\alpha$ gustducin yang ada di brush border sel intestinal. Kemudian ikatan rasa manis dan subunit reseptor T1R3 serta $\alpha$ gustducin dipresentasikan ke sel enteroendokrin yang bertanggung jawab pada reseptor glukosa di usus serta regulasi glucosa transporter untuk absorpsi gula dari membran usus halus. Kemudian sel enteroendokrin melepaskan hormon incretin seperti, Glucose-Dependent Insulino- Tropic Peptide (GIP) dan Glucagon-Like Peptide1 (GLP-1).

Menurut Margolskee (2007) GLP-1 memiliki reseptor di pankreas dan mengakibatkan peningkatan sekresi dan sintesis insulin. GLP-1 dapat meningkatkan sintesis insulin dengan cara menghambat apoptosis sel $\beta$ pankreas, merangsang proliferasi dan neogenesis sel $\beta$, serta meningkatkan 
sensitivitas pankreas terhadap glukosa. GLP-1 terikat pada reseptor spesifik di pankreas yang menyebabkan peningkatan kalsium intrasel sehingga terjadi sinyal tranduksi dan eksositosis insulin. Berdasarkan Campbell (2013) Aktivasi GLP-1 dengan reseptor di pankreas juga berpengaruh terhadap sel $\alpha$ pankreas berupa penurunan sekresi glukagon sehingga menekan produksi glukosa oleh hati atau glukoneogenesis. Mekanisme hormone GIP dan GLP1 inilah yang menyebabkan kadar glukosa darah pada hewan coba tidak mengalami perbedaan yang signifikan.

Tabel 2. Kadar Haemoglobin

\begin{tabular}{ccccc}
\hline & & \multicolumn{3}{c}{ KEL. PERLAKUAN } \\
NO & KEL. & $\mathbf{1 3}$ & $\mathbf{3 9}$ & $\mathbf{7 8}$ \\
& KONTROL & mg/Kg & mg/Kg & mg/Kg \\
& & BB & BB & BB \\
\hline 1 & 18,5 & 15,5 & 18,1 & 17 \\
2 & 18,9 & 16,8 & 15,4 & 14 \\
3 & 15,3 & 15,6 & 19,8 & 16 \\
4 & 15,9 & 17,9 & 16,6 & 18,4 \\
5 & 17,5 & 16,8 & 14,3 & 22 \\
6 & 15,5 & 17,9 & 12,9 & 15 \\
\hline & $\mathbf{1 6 , 9 3}$ & $\mathbf{1 6 , 7 5}$ & $\mathbf{1 6 , 1 8}$ & $\mathbf{1 7 , 0 7}$ \\
\hline
\end{tabular}

Sumber: Data Primer, 2018

Berdasarkan tabel 2 terdapat penurunan rata-rata kadar $\mathrm{Hb}$ mencit (Mus musculus) pada kelompok pemberian aspartam $39 \mathrm{mgKg}$ BB yaitu 16,18 g/dL. Hasil uji statistik dengan Kruskal Wallis di dapatkan nilai 0,899 p>0,05 sehingga Ho diterima Ha ditolak tidak ada perbedaan kadar $\mathrm{Hb}$ pada mencit yang diberi variasi dosis aspartam.
Hemoglobin merupakan sebuah komponen dari sel eritrosit dan merupakan protein yang berfungsi sebagai konjugat pada mekanisme transport oksigen dan karbondioksida. Penentuan kadar haemoglobin biasa dilakukan untuk mengetahui adanya kondisi anemia (Tahono dkk., 2000). Kadar haemoglobin pada kelompok perlakuan aspartame dosis 13, 39, dan $78 \mathrm{mg} / \mathrm{Kg}$ BB tidak memberikan dampak yang signifikan, hal ini dimungkinkan karena peran sistem pertahanan tubuh atau imunitas pada hewan coba, sehingga tidak mempengaruhi peningkatan ataupun penurunan kadar haemoglobin pada hewan coba. Sesuai hasil penelitian Aisyah (2003), yang menyatakan bahwa dimungkinkan pemberian pemanis buatan dosis tinggi dapat menyebabkan hewan coba memberikan reaksi imunitasnya sehinggal tidak menunjukan hasil yang signifikan.

Tabel 3. Kadar Kolesterol

\begin{tabular}{ccccc}
\hline & \multirow{2}{*}{ KEL. } & \multicolumn{3}{c}{ KEL. PERLAKUAN } \\
NO & $\begin{array}{c}\text { KONTRO } \\
\text { L }\end{array}$ & $\begin{array}{c}\mathbf{1 3} \\
\mathbf{m g} / \mathbf{K g}\end{array}$ & $\begin{array}{c}\mathbf{3 9} \\
\mathbf{m g} / \mathbf{K g}\end{array}$ & $\begin{array}{c}\mathbf{7 8} \\
\mathbf{m g} / \mathbf{K g}\end{array}$ \\
& & $\mathbf{B B}$ & $\mathbf{B B}$ \\
\hline 1 & 244 & 244 & 160 & 211 \\
2 & 116 & 108 & 181 & 267 \\
3 & 248 & 117 & 139 & 152 \\
4 & 116 & 101 & 182 & 179 \\
5 & 184 & 139 & 196 & 331 \\
6 & 131 & 154 & 180 & 174 \\
\hline & $\mathbf{1 7 3 , 1 7}$ & $\mathbf{1 4 3 , 8 3}$ & $\mathbf{1 7 3 , 0 0}$ & $\mathbf{2 1 9 , 0 0}$ \\
\hline
\end{tabular}

Sumber: Data Primer, 2018 
Berdasarkan tabel 3 terdapat peningkatan rata-rata kadar kolesterol mencit (Mus Musculus) terutama pada kelompok dosis $78 \mathrm{mg} / \mathrm{Kg}$ BB yaitu 219 mg/dL. Hasil uji statistik dengan Kruskal Wallis di dapatkan nilai 0,168 p> 0,05 sehingga Ho diterima Ha ditolak tidak ada perbedaan kadar kolesterol pada mencit yang diberi variasi dosis aspartam.

Pada perlakuan mencit betina memiliki kadar kolestrol yang cukup tinggi. Namun menurut Rosita (2016), dosis berbeda-beda yang tinggi belum tentu dapat memberikan efek yang baik pada hewan coba. Menurut Adi (2008), tingginya kadar kolestrol di dalam darah dapat diakibatkan oleh makanan, obesitas, merokok dan kurangnya berolahraga. Menurut Smith dan Mangkoewidjojo (1988), kadar kolestrol total normal pada mencit (Mus musculus) yaitu 126-82,4 mg/dl, akan tetapi semua mencit memiliki kadar kolestrol yang jauh di atas angka normal tersebut. hal ini dikarenakan kemungkinan dari faktor fisiologis dari mencit, dimana ketidak mampuan hati sebagai tempat pembentukan kolestrol untuk mengeskresikan kolestrol lama dari darah ke empedu, sehingga kadar kolestrolnya dominan tinggi, juga dapat disebabkan karena faktor genetik dari mencit itu sendiri (Sherwood, 2003).
Faktor lain juga dapat diakibatkan karena kondisi mencit yaang stres, dimana pada kondisi tersebut akna mengaktifkan sistem saraf simpatis yang menyebabkan pelepasan epifirin dan non epifirin yang akan meningkatkakn konsentrasi lemak bebas dalam darah (Guyton \& Hall, 1997).

\section{KESIMPULAN}

Tidak ada perbedaan kadar glukosa, $\mathrm{Hb}$ dan kolesterol pada mencit (Mus musculus) yang diberi variasi dosis aspartam

\section{DAFTAR PUSTAKA}

Aisyah, R., Listyawati, S., dan Widiyani, T. 2003. Efek Pemberian Natrium Siklamat secara Oral terhadap Karakteristik Hematologis Tikus Putih (Rattus norvegicus L.). Biosmart, Vol:5, No:2, Hal: 124-130.

Adi, L. T. 2008. Tanaman Obat Untuk mengatasi Penyakit Jantung, Hipertensi, Kolestrol, dan Stroke. PT Agromedia Pustaka, Bandung.

Campbell, Neil. 2004. Biologi. Edisi Ketiga. Erlangga, Jakarta.

Campbell JE, Drucker DJ. Pharmacology, Physiology, and Mechanisms of Incretin Hormone Action. Cell Metabolism. 2013; 17: 1-19.

Cahyadi, W. 2009. Analisis dan Aspek Kesehatan Bahan Tambahan Edisi ke 2. Bumi Aksara, Bandung. 
Dalimartha, Setiawan. 2007. Tanaman Tradisional untuk Pengobatan Diabetes Mellitus. Penebar Swadaya, Jakarta.

Guyton, A. C. \& Hall, J. E. 1997. Buku Ajar Biologi Kedoteran. EGC, Jakarta.

Ganong, WF. 1995. Buku Ajar Fisiologi Kedokteran. EGC, Jakarta.

Homler, BE., Ders, RC., and Shazer, WH. 1998. Alternatif Sweetners. Marcel Dekker, Inc. New York.

Margolskee RF, Dyer J, Kokrashvili Z. T1R3 and Gustducin in Gut Sense Sugars to Regulate Expression of Na+-Glucose Cotransporter 1. Proc Natl Acad Sci USA. 2007; 104: 15075-80.

Murray, RK, Granner, DK., Mayes PA., and Rodwel, VW. 2006. Biokimia Harper. Edisi 25. Penerbit Buku Kedokteran EGC, Jakarta.

Renwick AG, Molinary SV. Sweet-taste Receptors, Low Energy Sweeteners, Glucose Absorption and Insulin Release. British Journal of Nutrition. 2010; 104 :1415-20.

Rosita, F. 2016. Pengaruh Ekstrak Bawang Hitam (Black Garlic) Terhadap Penurunan Kadar Gula Darah pada Mencit (Mus musculus) Berdasarkan Lama Pemanasan. Karya Tulis Ilmiah. Akademi Analis Farmasi dan Makanan, Putra Indonesia Malang.

Tahono, Hadiwidodo, Yuwono dan Wuryaningsih. 2000. Patologi Klinik I - Pengantar Analisa Laboratorium Patologi Klinik Fakultas Kedokteran. Surakarta: UNS Press.
Sherwood, L. 2003. Fisiologi Manusia dari Sel ke Sel. Edisi 2. Penerjemah Brahm U. Pendit. EGC, Jakarta. 